\title{
The Contribution of Small and Medium Enterprise toward Economic Growth in South Sulawesi
}

\author{
Dr Anwar Ramli SE, MS.i \\ Department of Management \\ Faculty of Economy, State University of Makassar \\ South Sulawesi, Indonesia,
}

\begin{abstract}
Qualitative research with phenomenological approach as for the data source in this study include: 1) Primary Data Sources, 2) Secondary Data Sources. This research instrument is the researchers themselves, where the researcher as an instrument to obtain accurate data supplied by a variety of methods. The results showed that the experience of the current economic crisis hit Indonesia has proven that economic activity in the form of little people Small and Medium Enterprises constitute a major part in the economic activity of society that is able to withstand the storm of crisis as well as on South Sulawesi . Small and medium enterprises ( SMEs) has made a major contribution in the economy of Indonesia, both in terms of the amount of effort (establishment) and in terms of job creation
\end{abstract}

Keywords: Small and Medium Enterprises, Economic Growth and Entrepreneurship

\section{INTRODUCTION}

Economic growth is an economic problem in the long term. This study briefly. Rapid economic growth is an important phenomenon experienced by the world only since the past two centuries. The period in the development of the world has changed very real compared with the previous period. Until the 18th century most people in many countries are still alive on the stage of subsistence and livelihood primarily from activities in agriculture, fishing or hunting.

In terms of economics, the development of the world economy since two centuries ago gave rise to two important effects on promoting namely: (i) prosperity or increasing the living standards of the community, and (ii) it can create new employment opportunities to the growing population number. The issue of economic growth is always considered in the macroeconomic analysis is the problem of sluggishness of economic growth over time. In chapter one and some other chapters have stated that in general the various economic growth slower than the rate of growth that can potentially accomplish. The effect of these circumstances, the economy is not always achieve full employment and unemployment problem is a challenge that always must be faced and overcome in a long time.

Analysis of the economic growth is one of the important aspects of macroeconomic theory. Analysis was basically concerned about the state of economic activity in the long term. Small and medium enterprises (SMEs) in Indonesia is a major player in economic activity. They are an accelerator in community economic development. Micro businesses has been proven to be as reliable as a safety valve in times of crisis, through the mechanism of job creation and enable dihimpunnya state income tax form. The role and function of this strategic, can actually be improved by Small and medium enterprises play as one of the businesses complementary to 
the development of the national economy. Therefore, it is researchers interested in studying how the contribution of small and medium enterprises to the economic pertubuhan South Sulawesi.

\section{PROBLEM}

How Contributions of Small and Medium against Economic GrowthSouth Sulawesi

\section{LITERATURE REVIEW}

Definition of small and medium enterprises can be seen from several aspects. In the Indonesian economy, small and medium enterprise sector plays an important role, especially when associated with the amount of labor that can be absorbed by the small and medium enterprises. In addition to having a strategic significance for development, small and medium enterprises also serves as a means to equalize the development results that have been achieved. As for the part of small and medium enterprises are: agriculture, trade, trade, trade, mining, processing, service sector, and others. There is some understanding of small and medium enterprises of various opinions TulusTambunan, among others:1) Definition of small businesses based on Bank Indonesia Circular Letter No.26 / I / UKK dated May 29, 1993 regarding Small Business Credit (KUK) is a business that has total assets of Rp60 million (six hundred million rupiah) not including land or occupied homes. Definition of small businesses include private businesses, private enterprises and cooperatives, all assets owned does not exceed the value of Rp600 million.2) According to the ministry of industry and trade, small and medium enterprises are a group of modern industry, traditional industries and crafts industry, which has investment capital for machinery and equipment amounting to $\mathrm{Rp} 70$ million down the investment risk capital / labor Rp 625,000 down and the business owned by Indonesian citizens.3) According to the Central Bureau of Statistics, medium-sized businesses are divided into several sections, namely: (i) Business rumag have a ladder: 1-5 of labor, (ii) Small and medium enterprises : 6-19 of labor, (iii) medium Enterprises: 20 -29 workforce, (iv) Large businesses: more than 100 workers.4) While the concept Inpres Small and medium enterprises , the definition of Small and medium enterprises is economic activity with the following criteria: (i) Asset Rp 50 billion, not including land and buildings, (ii) The turnover of USD 250 billionWhile based on Law No.10 / 1995 on small businesses, which are defined as small businesses are the economic activities of the people are small-scale to meet the criteria of net worth or annual sales and ownership as stipulated in this law. What is meant here include informal small businesses also are a variety of businesses that have not registered, not yet recorded, and has not been incorporated, and traditional small business is the effort that has been used for generations, and relating to the arts or culture. University Of Northern SumatraThere are two main perspectives on the process of internationalization of small and medium enterprises (Small and medium enterprises). The first to feel the internationalization of Small and medium enterprises as a sequential process that leads from the domestic market to the international market in accordance with the "learning process," in which newly acquired knowledge of the market and increased resources are committed to this market (Johanson and Vahlne 1990, 1977; Cavusgil 1980; Bilkey and Tesar 1977 at the Julia M. Armario, David M. Ruiz, and Enrique M. Armario, 2008).The second perspective, derived from international entrepreneurship literature, argues that companies can "born global" (Rialp, Rialp, and Knight and WictorAndersson, McDougall, Oviatt, and Shrader, Kuemmerle, McDougall and Oviatt, Madsen and Servais, knight and Cavusgil, McDougall, Shane, and Oviatt in Julia M. Armario, David M. Ruiz, and Enrique M. Armario, 2008). The current state of research indicates that, in mature industries where environmental change is minimal, sequential perspective on internationalization is more appropriate, whereas, in a growing industry.SME sector is often regarded as a homogeneous, behavior and explain the size of its defining characteristics. While size is a factor, and many Small and medium enterprises as possible in accordance with such a 
view, there are other internal and external dynamics that describes the characteristics of their behavior. SME behavior is often understood in terms of the psychological characteristics of entrepreneurs or 'manager owner'; Small and medium enterprises tend to have a personal style of management and a lack of formal management structure with specialized staff (Bolton in heledd Jenkins, 2009).Encourage innovation in small and medium enterprises ( Small and medium enterprises ) remain at the heart of policy initiatives to stimulate economic development at the local, regional, national and European level (Jones and Tim Tilley in Edwards, Rick Delbridgeand Max Munday, 2005). In the UK, this can be traced back to the rise of the New Right in the 1980s and the death corporatist perspective of 'big is beautiful and its replacement with an entrepreneurial logic in stimulating economic growth (Hutton, in Tim Edwards, Rick Delbridge and Max Munday, 2005). At the theoretical level, innovation has also been replaced efficiency as an important focus of a lot of theory building and policy analysis with additional efficiency to be necessary for innovation (Clark and Staunton, in Tim Edwards, Rick Delbridge and Max Munday, 2005).Small and Medium Enterprises (Small and medium enterprises) have demonstrated the increasingly strong position in the important role of Small and medium enterprises in economic growth in national development policies. The issue and the industry of a country (Husband and Purnendu, the fundamental of this is how 1999; Mahemba, 2003; Tambunan, 2005). Enterprises implementing these policies, little important to be studied because it has so Small and medium enterprises in Indonesia actually became a crucial role in economic growth in the economic actors that have a major contribution to national and regional scale. Almost $90 \%$ of the total businesses in the world is the contribution of the SME (Lin, 1998).Definition and character of small and medium enterprises in Indonesia is still diverse and depend on the concepts used. Small businesses are often synonymous with employers economically weak so that is still a lot of disagreement about the definition of small business.Criteria for small businesses in Indonesia vary depending on the intended focus of the problem and in institutions related to the sector. The central body of Statistics (BPS) consistently from 1974 using the guidelines defining the amount of labor in small businesses when an attempt to use the amount of labor between 5 and 19 people categorized as Small Business.Department of industry, in 1990, suggested criteria for small businesses on the side finensial, ie the value of business assets (excluding houses and land), below Rp. 600,000,000. While according to the Chamber of Commerce and Industry (Kadin), the business sector is relatively small if it has an active capital in that Rp. 150,000,000. With a turnover of under Rp. 600 million per year, except for the construction sector with restrictions having active capital below Rp. 250,000,000. with a turnover of less than Rp. 1 billion per year.In 1990 Bank Indonesia determines the criteria of small businesses from the financial side, the businesses whose assets (not termsuk land and buildings), below Rp. 600,000,000. With the Law on Small Business, then at least there is no formal reference on the definition of a small business. In Law No.9 / 1999 on the Small Business mentioned that small businesses are the economic activities of the people are small-scale and meet the criteria of net worth / annual sales and ownership as stipulated in this Law. To more clearly by using the net asset value figures, described in the Law No.9 / 1999 stipulated that small business is a business unit that has a net asset value (excluding land danbangunan) that does not exceed USD. 200 million, or sales per year is not greater than 1 billion. Meanwhile, according to Presidential Decree No. The 10/1999, Medium Enterprises is a unit with a net asset value (excluding land and buildings) between Rp 200 million to $\mathrm{Rp} 10$ billion.B. Economic GrowthEconomic growth explain or measure the achievement of the development of an economy. In the growth of economic activities which actually means the physical development of the production of goods and services existing in the country, such as the increase and the amount of production of industrial goods, infrastructure development, increase the number of schools, the development of the service sector production and increase the production of capital goods. But by using different types of 
production data is very difficult to give an overview of the economic growth achieved. Therefore, to give a rough idea as to achieve economic growth in a country, the size of which is always used is the rate of growth of real national income is achieved.Intuition is quite simple: If the underdeveloped financial markets, then people will choose less productive, but 'flexible' technology. Given this technology, the manufacturer did not experience a lot of risk, and therefore there is very little incentive to develop the financial markets. Conversely, if the financial markets are developed, the technology will be more specialized and risky, thus creating the need for the financial markets. in the terminology Cooper and John (in Gilles SaintPaul, 1992), there is complementarity between the strategic financial markets and technology, since both are instruments that can be used to diversify.

A developing country could suffer from the second gap at the same time. In addition, the gap does not distinguish between the two is important to achieve some policy conclusions. According to one view, the functioning legal system, a stable monetary policy, and effective support for education will all desired policy objectives because they can help reduce the gap (Paul Romer, 1993).C. Classical Growth TheoryAccording to the views of the classical economists, there are four factors that affect the economy, namely the total population, the number of stocks of capital goods, land area and natural resources, as well as the level of technology used. Although aware that economic growth depends on many factors. Expert classical economists primarily focuses its attention to the influence of population growth economic growth. According to economic experts view as well, the law of diminishing returns additional results will affect economic growth. This means that economic growth will not continue to take place.a. Schumpeter's theoryShumpeter theory emphasizes the importance of the role of entrepreneurs in realizing economic growth. In theory it is shown that the employer, a group that will continue to make reforms or innovations in economic activity.In the theorized growth shumpeter begin its analysis by letting the economy is in a state of growing, but this situation does not last long. At the time of these circumstances apply, a class of entrepreneurs aware of the possibilities to conduct profitable innovation. Driven by the desire to benefit from the reforms held, they will borrow and undertake investment capital (investment).b. Theory of Harrod-DommarIn analyzing menegenai economic growth, Harroddommar theory aims to explain the requirements that must be met so that an economy can achieve growth teguhatausteedy growth in the long jangaka. Harrod-dommar analysis using the analogy analogy: (i) capital goods has reached full capacity (ii) saving is proportional to the national income (iii) capital ratio of production (capital output ratio) (iv) comprises two sectors of the economy.c. Neo Classical growth theory as an extension of Keynes theory, the theory of Harrod-Dommar see the issue in terms of demand growth. Economic growth is only applicable if agregat- expenditure through increased investment-increasing continuously at the prescribed rate of growth.

The most important contribution of neo-classical growth theory is not to show the factors that influence economic growth, but the contribution to use the theory to conduct empirical investigation in determining the exact role of the various factors of production in realizing economic growth D. EntrepreneurshipIn the early 20th century, entrepreneurship or entrepreneurship into a warm study because of its crucial role in economic development. Is Schumpeter (1934) which says that if a country has a lot of entrepreneurs, the country's high economic growth, which will bear the high economic development? If a country wants to go forward, the number must be much entrepreneurnya. Enterprenuership is the driving force behind economic growth. Kirzner said that entrepreneurship is an important part in the construction.Rationalization is if someone has the entrepreneurial, he will have the characteristics of motivation / high dream (need of achievement), dare to try (risk taker), innovative and independence. By this nature, with few chances and opportunities, he was able 
to transform, to produce something new, a new relationship, the accumulation of capital, both in the improvement of existing enterprises (upgrading) as well as generate new business. With this effort, will move the material / raw material for the "change shape" a more valuable so that ultimately consumers want to buy. In this process there will be exchange of goods and services, either in the form of natural resources, money, social resources, opportunity and human resources. In economics, if this happens, it means that there is economic growth, and if there is economic growth means there is development.In the case of the state, we can learn from Japan, where the time World War II, they were crushed. However, because of the accident, the Japanese nation was more powerful than ever because after that, the Japanese government reforms in all fields with the two pillars, namely the dissolution of the conglomerate and the anti-monopoly law. In the agricultural sector, which is the earliest cultivated agricultural land reform.System "landlord", which is one form of conglomeration in agriculture is removed, and the "landlord" is prohibited from owning land area is too large. The land is criss-crossed, and each owner of land tilled by farmers themselves. If before a landlord has an area of 8000 ha of land until now farmers in Japan have an average land area of 1.5 ha (except farmers on the island of Hokkaido). This policy has had a huge impact on economic development in Japan.It is common knowledge that the Japanese are hard workers. The average hours worked by employees in Japan is 2450 hours / year, very high compared with the US (1957 hours / year), England (1911 hours / year), Germany (1870 hours / year), and France (1680 hours / year), An employee in Japan could produce a car in 9 days, while workers in other countries require 47 days to make the car worth the same. A worker can be said Japan can do the work normally done by 5-6 people. Home quickly is something that can be said "somewhat embarrassing" in Japan and signifies that the employee was included "not required" by the company.On campus, the professor also used to return the night (actually early), making the students did not enjoy home first. The phenomenon of Karoshi (death due to hard work) may only exist in Japan. Most of the literature mentions that the hard work is actually the revival and prosperity of Japan can be achieved. One of the causes of failure in achieving economic growth and economic development of a country in the absence of entrepreneurship both in the level of individuals, organizations and society.Researchers have previously said, entrepreneurship plays an important role in economic development (Kirzner, 1973), is a vital component of productivity and growth, contributed to the increased investment, new business creation, led to job training and home-base business (Spencer Hull, 1986), improving employment growth, the creation of national identity and leadershi and together with management capacity determine the success of the business (farm performance) (Priyanto, SH, 2005).Schumpeter (1934) even stated that enterprenuership is the driving force behind economic growth, formulating new economic combination by (1) developing new products; (2) developing new sources of materials; (3) accumalating capital resources; (4) introducing new products and new production functions; and (5) reorganizing or developing a new industry.1. The idea of entrepreneurship based on economic activityClassical period (Around the year 1700 until the 1800s). Cantillon (1755) introduced the concept of entrepreneurship in the trade literature, economics and business. Her work (Cantillon, 1755) which defines the mismatch between supply and demand, legalizing to buy goods at a low price and sell at a price that is not definite and allocate goods on the market system. The movement follows the classical economic thoughtCantillon, namely the supply, demand and equilibrium.Economic actors / entrepreneurs who perform arbitration (sale of assets rated high and buyers of assets rated lower) experienced problems of uncertainty and risk. Innovation and coordination to be important in entrepreneurial activity, for example entrepreneurial activity performed by most of thefarmers had contracts with landowners to cultivate their land.Economic activity in the classical period dominated by three groups namely landowners (spend rent money to buy luxury goods), capitalists (save and invest profits into 
other fields) and workers (using his salary to purchase daily necessities). This condition is consistent with the statement that JB Say classical movement explains the role of entrepreneur / businessman make the process of production and distribution in a competitive market. Conditions at that time, there were three factors of production that can be managed the land, and human capital (labr) in the industry.Neoclassical period. This period began in the late 1800 s. Characterized by the emergence of the concept of diminishing marginal utility to explain the economic activities and open up a different perspective in addressing the relationship between individuals. The results are affected by the condition the market phenomenon of social, political and cultural. Being unique and entrepreneurial activity is seen as a transition / change science, which seeks entrepreneurial activity change / transform resources into the service of products / services.It is difficult to predict due to uncertainty. Increasingly sophisticated economic thinking during the neoclassical movement. At this time the employers are more inclined to the resource allocation of the accumulated capital (Schumpeter, 1934). From this trend, the entrepreneurial activity will introduce new products, the production model, and the creation of markets as well as new organizational forms. Entrepreneurship involves innovation to encourage the creation and find something new. Schumpeter describes aspects of innovation made by employers as creative destruction, but it can be recovered by other market participants are trying to balance the market system. The period of the Austrian market (AMP / Austia Market Process). Of neoclassical thought at the time that to know the economic phenomena (in order to find opportunities) do not need to search for all information related to the economic system. However, if this is done then a job that is not practical. Obviously it takes specialized knowledge entrepreneurs to seek opportunities and make the right decisions. If employers know how to create goods or services through innovation or know a more precise way to do it, then the benefits can be obtained through this knowledge.Rather, employers are encouraged to use the knowledge to gain value. At the time of this AMP concentrate entrepreneurs to find the information with all the knowledge that they have to find and execute opportunities and take appropriate decisions. Based on the ideas of neoclassical (Scumpeter, 1934), AMP becomes part of entrepreneurship that drive market-based system.

\section{RESEARCH METHODS}

This study describes and analyzes the contribution of small and medium enterprises (Small and medium enterprises) to the economic growth of South Sulawesi. Based on the type of research in which use of qualitative research methods, this study using phenomenological approach Sources of data in this study included: Primary Data Sources. And Secondary Data Sources.

\section{DISCUSSION}

How Contributions of Small and Medium on GrowthEconomic South SulawesiThe Role of Small and Medium Enterprises ( Small and medium enterprises ) in Idonesia is very large and has been proven to save the nation's economy during the neconomic crisis in 1997, said the Central Executive Council of the Indigenous Indonesian Entrepreneurs Association (Hippi DPP), Suryo B.Sulisto, MBA.

The government's policy today has enough stood for small and medium enterprises. Many have been the efforts and government measures regarding the empowerment of the small and medium enterprises in the past five years. Government policies to favor the Small and medium enterprises it is a very appropriate step to raise the nation's economy.In countries majupun, both in the United States, Japan, Germany, Italy, Small and medium enterprises have been the main pillar of the country's economy. The situation was only possible because of government than these countries have policies that support the creation of conditions in which small and 
medium businesses they became very healthy and strong.Proved during the global crisis that occurred some time ago, Small and medium enterprises present as a solution of a healthy economic system. SME industry is one sector that is little or not at all affected by the global crisis that hit the world. With this evidence, it is clear that Small and medium enterprises can be taken into account in improving market competitiveness and economic stabilization of the existing system. In economic development in Indonesia SME sector, which has always portrayed as having an important role, since most of the population is poorly educated and live in small business activities in both the traditional and modern. The role of small businesses that become part of precedence in the planning stages of development that are managed by the two departments, namely the Department of Industry and Trade, as well. Ministry of Cooperatives and Small and medium enterprises. However, the business development that has been implemented is still not satisfactory result because in reality the progress of Small and medium enterprises is very small compared with the progress made great efforts. SME policy implementation by the government during the New Order, few are implemented, more just a slogan only so the result was not satisfactory. The Government is in favor of the large employers in almost all sectors, including trade, banking, forestry, agriculture and industry.And now, according to Trade Minister Mari ElkaPangestu said that Small and medium enterprises have a very important role in ASEAN, including Indonesia. During the Small and medium enterprises continues to demonstrate its ability to survive and remain dynamic. We need to involve Small and medium enterprises and ensure that Small and medium enterprises benefit from the ASEAN Economic Forum (AEC) to realize the ASEAN goal of inclusive, equitable, sustainable, and has high durability. Based on data from the Secretary General of ASEAN, Small and medium enterprises employ 50 percent and 96 percent of the number of workers and contribute between 19 percent to 31 percent of total exports in ASEAN.For the people of South Sulawesi sector of Small and Medium Enterprises (Small and medium enterprises) is one of the locomotive engine that is crucial for economic growth and development in many areas in the province. In developed countries, such as Japan, the growth rate is very rapid economic often associated with the amount of the small business sector.In the United States a very large contribution of Small and medium enterprises in job creation since World War II (Anderson; in Partomo, 2004: 12-13). In this regard, developing countries began to change its orientation by empowering (empowering) the SME sector as a very important role and contribution of the Small and medium enterprises .The existence of the Small and medium enterprises sector in the economic development process of developing countries pressed and unrivaled by besar1serta scale business sector is often associated with economic problems and social, such as the high number of poverty, the magnitude of unemployment, unequal distribution of income, the process of development between urban and no average rural areas, as well as problems of urbanization with all its negative effects.There are at least three reasons underlying Sulawesi as part of developing countries recently looked at the important presence of Small and medium enterprises. The first reason is because the performance of Small and medium enterprises tend to be better in terms of generating a productive workforce. Secondly, as part of its dynamics, Small and medium enterprises often achieve increased productivity through investment and technological change. The third is because it is often believed that small and medium enterprises have advantages in terms of flexibility than large businesses. Small business and household enterprises in Sulawesi have played an important role in absorbing labor force, increase the number of business units and support household income.Experience when the economic crisis hit Indonesia has proven that economic activity in the form of little people Small and Medium Enterprises ( Small and medium enterprises ) constitute a major part in the economic activity of society that is able to withstand the storm of crisis as well as the Sul-Sel. Small and medium enterprises ( Small and medium enterprises ) has made a major contribution in the economy of Indonesia, both in 
terms of the amount of effort (establishment) and in terms of job creation.The crisis that hit Indonesia in 1998 turned out to bring the positive side for small and medium enterprises ( Small and medium enterprises ) that have an impact on almost all parts of Indonesia in the said South Sulawesi Province. Sectors that stand forged the crisis make the most of the banks that had been the focus shifted its strategy to become a retail corporation, including Small and medium enterprises. Not surprisingly, Small and medium enterprises then be excellent due to its characteristics resistant to shock the financial crisis.There are various reasons that make the small business sector can survive in times of crisis. One of them, this sector does not depend on imported raw materials in the production process, so the production cost is not affected by the soaring value of the rupiah against the dollar. In fact, if the products are exported, the benefits can accrue.Another reason for businesses that capitalize loans, small business sector does not get a loan from a foreign currency. The source of small business funding generally comes from within the country. In contrast to the large business sector is partly still dependent on imported raw materials.Assistant II for the Economy and Development of the Regional Secretariat of South Sulawesi Province, Drs. H. Salam Sidik open implementation of Enterprise Based Training Rural / Village se Makassar and Maros 2014, Monday, September 15th, 2014 at the Hotel Denpasar Makassar. "This activity is highly strategic momentum in building and developing entrepreneurship in South Sulawesi, and increase synergies between universities and the central government, local government and private sector," said Salam Sidik."Program development of entrepreneurship is one of the priority programs of the Provincial Government of South Sulawesi, namely the development of entrepreneurship based on rural / urban villages which aims to build a spirit of entrepreneurship," he continued.According to Salam Sidik, South Sulawesi Provincial Government with various priority programs that have been implemented in an effort to increase the acceleration of economic development in this region as policy and strategic program that involves all elements of society, especially economic actors that contribute to the achievement of economic growth in South Sulawesi in the first quarter amounted to 8,01 percent.

He hopes this event can be a momentum in bringing the perpetrators of entrepreneurs or small and medium enterprises (Small and medium enterprises) as a spearhead in promoting economic growth in South Sulawesi.Department of Cooperatives and Small and Medium Enterprises (Small and medium enterprises) in South Sulawesi Million Movement has launched Small and medium enterprises.

This movement is expected to be the locomotive driving and spearhead the economic development of South Sulawesi which has a variety of leading commodity. This movement is also expected to reduce unemployment, poverty and income distribution. How far that hope realized.From some of the indicators that we can see, I see economic growth in the province is quite good in the last five years. Based on the data that the economic growth of South Sulawesi in 2009 reached 6.20 percentage points increase to 8.65 percent in 2011. Since the last three years or entered in its fourth year, the economic growth we are always at the top of the national economic growth.

We look at the economic structure of South Sulawesi (Sulawesi). Which dominate the agricultural sector, trade, industry, and then services. That's where the Small and medium enterprises actually distributed. Examples farming unit, which many itukan farmers, later in the trade that dominates. So the role of Small and medium enterprises in economic growth Sulsel very big because he distributed both in developing the economic structure of the province.Good. Because of the economic structure is still dominated by the primary sector in South Sulawesi. That's where the role of Small and medium enterprises including cooperatives. 
Be strategic if the economy of this region is directed at Small and medium enterprises, because it is dominant. If we want to live high technology was dangerous...It is to be realized in 2013, is optimistic it can be achieved. Especially when it has reached 864 Small and medium enterprises. Currently the remaining one year more. So, I am very optimistic for the reduction of unemployment can be realized. This movement is suitable because of the advantages of these Small and medium enterprises do not require a lot of capital to form. Small and medium enterprises are also easily managed even though education levels of managers are not too high.Then there are the efforts made by the government to speed up its realization by creating new entrepreneurs. It is certainly connect with the national program. Stakeholders also supports such as banks who wanted to create a young entrepreneur.South Sulawesi province has programmed the construction industry in order to encourage the development of konsef One Village One Product via quotation program, though, and selling. With the approach as it means there is a shift from products created plucked immediately sold, and it is now processed. This is an added value generated our Small and medium enterprises. That was a first.The second is an attempt to increase the productivity of Small and medium enterprises, and improve the competitiveness of the products produced by the province. Remember, we are now in the era of globalization. It is needed to improve productivity, and increase competitiveness, South Sulawesi provincial government continues to encourage the creation of new entrepreneurs in the province through the development of education and training consistently and continuously.It was very positive, because one of the problems faced by managers of cooperatives and Small and medium enterprises is the problem of human resources. Problems such as managerial, creativity, and build a network is still lacking in HR have Cooperatives and Small and medium enterprises. Then, need training to create quality human resources. Indeed Sulawesi still one percent more, but it's been some efforts made by, among others, creating entrepreneur. Then create new entrepreneurs who not only conducted by the Ministry of Cooperatives and Small and medium enterprises but also by other stakeholders conducted as a bank.Live governments do things like facilitation, mediation, and coaching. Guidance should be focused because the government has limited resources and budget resources builder. Progress in the development of cooperatives and SME sector certainly has shortcomings in its implementation. Indeed there are many obstacles. It should be a challenge for the government and other stakeholders as well as an opportunity to make the barriers evolve in the future, for the long term the government needs to establish a credit guarantee institution. With the credit guarantee institution is then to be managers of Small and medium enterprises will be helped, including the existing cooperatives in the province to make it easier for them to access banking because there is guarantee.

\section{CONCLUSION}

The role of small businesses that become part of precedence in the planning stages of development that are managed by the two departments, namely the Department of Industry and Trade, as well. Ministry of Cooperatives and Small and medium enterprises. However, the business development that has been implemented is still not satisfactory result because in reality the progress of Small and medium enterprises is very small compared with the progress made great efforts. SME policy implementation by the government during the New Order, few are implemented, more just a slogan only so the result was not satisfactory. The Government is in favor of the large employers in almost all sectors, including trade, banking, forestry, agriculture and industry.

\section{References}

Cantillon, R. (1755), “Essaisur la Nature du Commerce in Ge'ne'ral”, Institutnational d'e'tudesde'mographiques, Paris. 
Gilles Saint-Paul. 1992. Technological Choice, Financial Markets and Economic Development", European Economic Review 34 (1992) 763-781. North

Heledd Jenkins (2009), “A 'business opportunity’ model of corporate social responsibility for small- and mediumsized enterprises”, Journal compilation r 2009 Blackwell Publishing Ltd., 9600 Garsington Road, Oxford, OX4 2DQ, UK and 350 Main St, Malden, MA 02148, USA, Business Ethics: A European Review Volume 18 Number 1 January 2009.

Husband, S. and Purnendu, M. (1999), "A Conceptual Model for Quality Inetgrated Management in Small and Medium Size Enterprise", international Journal of Quality \& Reliability Management, Vol. 16 No.7, pp. 699-713.

Julia M. Armario, David M. Ruiz, and Enrique M. Armario (2008), "Market Orientation and Internationalization in Small and Medium-Sized Enterprises", Journal of Small Business Management 200846 (4), pp. 485-511.

Kirzner, I. (1973). "The Entrepreneur”, Competition and Entrepreneurship. Chicago: University of Chicago Press, Chapter 2, pp. 30-87.

Lin, C. y. (1998), "Success Factors of Small-andMedium-Sized Entreprises in Taiwan: An Analysis of Cases", Journal of Small Business Management, Vol. 36, No, 4, pp. 43-65.

Priyanto, Sony Heru, (2002), "Pengembangan Kewirausahaandan Kapasitas Manajemen pada UKM Pertanian”, Jurnal Ekonomidan Bisnis Dian Ekonomi. Vol. III No. 3, 401-427.

Paul Romer. 1993. Idea Gaps and Object Gaps in Economic Development", Journal of Monetary Economics 32 (1993) 543-573. North-Holland.

Schumpeter, Josept A. (1934), "In theory of Economic Development: an Inquiryinto Profits, Capital, Credit, Interest, and The Business Cycle", Oxford University Press, New York.

Tim Edwards, Rick Delbridgedan Max Munday (2005), "Understanding innovation in small and medium-sized enterprises: a process manifest", Technovation 25 (2005) 1119-1127. 